\title{
Differing Federal Individual Income Tax Perceptions: Political Party Affiliation And Ideological Philosophy
}

\author{
Angeline Lavin, Ph.D., University of South Dakota, USA \\ David Moen, Ph.D., University of South Dakota, USA \\ Thomas Davies, L.L.M., University of South Dakota, USA
}

\begin{abstract}
Individuals who are affiliated with different political parties and who subscribe to different ideological philosophies also tend to have different views on many issues. This paper explores taxpayer perceptions of the federal individual income tax, which can be traced back to 1913 in its present form, based upon their political party affiliation as well as their ideological philosophy. The analysis revealed that the responses to the federal individual income tax statements included in this survey were not independent of political party or ideological philosophy. These results suggest that the political and ideological makeup of Congress and the President are likely to have an impact on future decisions with respect to possible modifications to the federal individual income tax. The question remains whether these differences may be set aside in a consolidated effort to find long range solutions to our country's fiscal challenges.
\end{abstract}

Keywords: Federal Income Tax; Political Party Affiliation; Ideological Philosophy; Taxation; Taxpayer Perceptions

\section{INTRODUCTION}

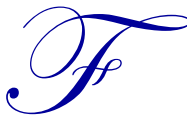

aced with the fiscal cliff, the next president of the United States will face a more difficult economic and fiscal situation than any President in recent memory. While some citizens would prefer that governmental leaders implement spending cuts while others would favor an increase in revenue, as a practical matter the country's precarious financial situation cannot be addressed exclusively by just one of these options. Of course, the most often discussed mechanism for generating additional revenue is through an increase in tax revenue. Several approaches could produce this result, including eliminating deductions and credits, increasing rates, or expanding the tax base. Discussions, whether held in our nation's capital or in some small town coffee shop, which center on taxes are usually heated and often divided along partisan lines or philosophical splits.

The current individual income tax system in the U.S. can be traced back to the passage of the $16^{\text {th }}$ Amendment to the Constitution in 1913. While the system is tinkered with annually, there have only been three codifications culminating with Internal Revenue Codes in 1939, 1954, and 1986. The highest marginal rates (i.e., the rate at which the next dollar of income is taxed) applicable to citizens have ranged from seven percent (19131915) to 94\% (1944-1945) (Citizens for Tax Justice, 2011), and are thus presently at the lower end of the range at $35 \%$. Similar to most countries, the tax rate structure in the United States is progressive in nature, meaning that as income goes up, tax rates also increase. In recent years, however, the top rates have declined worldwide, resulting in a "significant shift towards lower tax burdens, especially at the top of the income distribution" (Peter, Buttrick and Duncan, 2010).

The most significant changes to domestic tax law in recent years occurred in 2001 and again in 2003 when Congress passed tax laws proposed by President George W. Bush in an effort to boost economic growth (Auten, Carroll and Gee, 2008). Many of these resultant provisions were originally set to expire at the end of 2010, if not 
before. However, a compromise reached in December 2010 extended the cuts through the end of 2012; if these rules are not extended, taxpayers once again will need to reassess their own financial situations. However, it is likely that no decision regarding extensions or other modifications will be made until after the November 2012 election. If nothing is done during the "lame duck" session after the election, then the extended Bush cuts will expire on December 31, 2012, resulting in higher taxes for many taxpayers. In addition, automatic cuts to both mandatory and discretionary spending would take place. However, the lack of action will result in a so-called "fiscal cliff" which is expected to negatively impact real GDP growth and be "destructive to the economy and terrible for jobs" (Greeley, 2012).

Today, the amount of federal debt held by the public including foreign governments is about two-thirds of gross domestic product (GDP). The nonpartisan Congressional Budget Office (CBO) estimates that the percentage of federal debt held by the public will grow to 100 percent of GDP in ten years and 200 percent by 2040 . Given these projections, it seems unlikely that the federal budget can be balanced through spending cuts alone (Porter, 2012). In July 2012, President Obama proposed that families earning more than $\$ 250,000$ per year should contribute more by paying higher taxes. He proposed an increase in marginal tax rates to a maximum of $39.6 \%$, as compared to the current rate (Meckler and Paletta, 2012). In contrast, the Romney/Ryan plan focuses on simplifying the tax code and lowering tax rates (Ferguson, 2012). It is no surprise that each candidate's approach is similar to the strategy that most would associate as being consistent with their respective political party. Democrats, who generally tend to be more liberal, tend to favor progressive tax plans, higher tax rates on the wealthy and more governmental spending. In contrast, Republications, who tend to be more conservative, favor lower tax rates, a broader tax base, and less government spending. Of interest is a recent study by Frum which found that $46 \%$ of Americans were against the Obama approach which calls for higher taxes on wealthier citizens and more government employment and private sector stimulus; another $46 \%$ rejected the Romney plan that lowers taxes, cuts entitlement spending, and rolls back restrictions on the financial industry (2012). This tax debate certainly shows a stark divide between the presidential candidates and their respective parties. However, according to Meckler and Paletta (2012), both parties agree that they would like to see a comprehensive overhaul of the tax code. It remains to be seen if a tax overhaul will be on the congressional agenda in 2013. The authors report below the findings of their study which was undertaken to ascertain perceptions of taxpayers regarding federal income tax policy and related issues in hopes of providing future direction for decision makers.

\section{LITERATURE REVIEW}

\section{The Federal Income Tax}

As the so-called "fiscal cliff" looms and the country moves forward after the national election, questions and concern remain as to how to best address the country's current economic situation including its growing budgetary deficit. The two candidates for president have proposed divergent plans; and elected officials from the two major parties have demonstrated an unwillingness or inability to work together in an attempt to reach a compromise solution.

To a certain extent, there is a bias toward maintaining the present tax structure, especially given that bipartisan support is typically required to make changes. Burman, Gale, Leiserson, and Rohaly (2007) studied the alternative minimum tax (AMT) and offered 23 potential options for reforming the tax, noting that a significant barrier to AMT reform is the challenge of what to do about lost revenue given that the AMT is expected to provide nearly one trillion dollars in tax revenue from 2007 to 2017. While the regular income tax contains features that are considered by some to be inefficient or inequitable, many citizens believe that the AMT is not only inequitable but also extremely complex. However, it is argued that it is difficult to make changes because they all produce winners and losers. Some would say that the ideal solution would be a complete overhaul of the income tax, but achieving bi-partisan support for that type of ambitious undertaking would be an uphill battle. Historically, these types of proposals, such as the flat tax, have not succeeded. In addition, it is not possible to precisely predict the financial impact of a major overhaul in the tax code due to the behavioral response of individuals in response to changes in tax law (Feldstein, 2008). Feldstein (2008) points out that official analyses of tax rate increases tend to overstate the resulting revenue gain, while official analyses of tax rate reductions tend to overstate the resulting revenue losses. Acuna and Holcombe (2010) specifically studied the reported income for high income taxpayers and found, 
not surprisingly, that their income rises when they face lower tax rates. They also found, however, that the income of high income taxpayers also rises in response to lower tax rates on non-high income taxpayers, which suggests the potential for structural effects of tax changes that may not be fully understood or accounted for when revenue projections are made.

One potential incremental step toward improving revenue collection and addressing our financial crisis is better tax compliance and collection. To the extent that more of the tax that is due to the IRS could be collected, the revenue needed to finance tax reform would be reduced (Burnam et al, 2007). In contrast, Hofmann, Hoelzl and Kirchler (2008) explain that in a climate characterized by mutual trust, citizens tend to cooperate spontaneously with the tax system and tax authorities. Perceived fairness of the tax system also increases the tendency to cooperate or voluntarily comply with the tax system. Another element of "fairness" as described by Auten and Gee (2009) is whether individuals have the opportunity to move up in the income distribution over time. This is also known as "income mobility," and, according to Litan (1999) the opportunity for upward mobility as a result of individual effort is sometimes seen as a defining characteristic of the U.S. economy. Auten and Gee (2009) found that there was indeed considerable income mobility over the 1987-1996 and 1996-2005 time periods with roughly half of the taxpayers in the bottom income quintile moving up to a higher income group by the end of each time period.

\section{Politics and Philosophy}

Considering the public's general lack of general consensus regarding the income tax options being proposed, it is not unreasonable to think that Republicans and Democrats may be divided by party lines as to what direction to follow. Ackerman and Altshuler (2006) write that gaining bi-partisan support for changes in tax law is typically difficult and thus likely the reason why the President's Advisory Panel (Panel) on Federal Tax Reform appointed by President George W. Bush failed to propose dramatic reforms or a sweeping change to the current system. Therefore, the recommendations that were part of the Panel's 2005 report were the result of compromise. While the Panel managed to put forth a unanimous report, this compromise served as a constraint that dramatically impacted the Panel's final recommendations (Ackerman and Altshuler, 2006).

The inability of Congress to achieve bi-partisan support for changes to the tax law strongly suggests that opinions about tax policy may be related to either political party affiliation or philosophical ideology. Indeed, party identification is included as an explanatory variable in almost every study of public opinion or electoral behavior. As Jacoby (1988) described, group norms provide standards for individual behavior. Political parties can indeed provide norms that help citizens organize and structure their own beliefs on a variety of issues including economic and fiscal policy. Thus, party attachments provide many citizens with a convenient mechanism for structuring their own responses to matters of public policy (Jacoby, 1988).

Hetherington (2001) studied citizen perceptions of political parties in the United States during the 1990's. He found that Americans tend to think about one party positively and the other party negatively and are less likely to be neutral with respect to either party. In addition, voters were also more likely to be able to articulate why they liked and disliked each party as compared to prior years. Like Bartels (2000), Hetherington found evidence that political parties in the electorate have rebounded significantly since 1980, while Miller (1998) found that the proportion of Republican and Democrat voters was nearly equal in the late 1990's. Therefore, national elections significantly influenced by party affiliations should be expected to be very close. Indeed, the Bush-Gore election of 2000 served as a perfect example of that phenomenon.

According to the results of a June 2012 Wall Street Journal/NBC News poll of 1,000 citizens, Americans are split almost evenly on the following question, "What is closer to your point of view: Government should do more to solve problems and help meet the needs of people, or government is doing too many things better left to businesses and individuals," Forty-seven percent of those polled said that the government was doing too much, while $49 \%$ believed the government should do more. The partisan divide was nearly perfect as well; $75 \%$ of Democrats said the government should do more, but $76 \%$ of Republicans said the government should do less (Seib, 2012). 
The Economic Growth and Tax Relief Reconciliation Act of 2001 (EGTRRA) and the Jobs and Growth Tax Relief Reconciliation Act of 2003 (JGTRRA) were passed by Congress and incorporated the main elements of the Bush Administration's tax proposal according to Auten, Carroll and Gee (2008). The acts were passed in an attempt to improve the economic incentives to work and invest by reducing the tax rate and tax burdens on U.S. citizens. The 2001 tax cut passed both the House and the Senate by a clear majority. While all Republicans in each chamber voted yes, there were Democrats in each chamber who also supported the bills as well.

The fact that the 2001 and 2003 tax cuts were passed with bi-partisan support suggests that under some circumstances politicians will cross party lines to support particular measures. This study seeks to shed additional light on the perceptions citizens have toward the federal income tax, based upon their political and ideological perspectives, in hopes of finding common ground which will incent elected representatives to work together to address our country's financial crisis.

\section{PRESENT STUDY}

Undergraduate and graduate students taking select fall 2011 business and accounting classes at a mid-sized Midwestern university were given the opportunity to participate in a research study and earn extra credit points by administering up to five questionnaires (including completing one themselves) on the federal individual income tax. Students who participated in the survey process were asked to adhere to several rules. The student could ask no more than one other student to complete a survey, and only where this second student had not already completed the survey and met the other conditions explained herein. No more than two surveys could be completed by a member of the student's immediate family (parents, grandparents, children, grandchildren, brothers and sisters). In addition, no more than one survey could be completed by an employee of the university. Further, survey participants needed to be at least 18 years of age as well as required to have previously filed a federal income tax return. Students were encouraged to seek diversity in survey participants, including differences where possible in gender, age, education, profession, and income level. Students were encouraged to ask people from outside of the college community to participate. Students were also asked to verify that the people they asked to complete the survey had not completed it for someone else. To encourage compliance with the guidelines, a log was provided for students to submit the names and addresses of the individuals who had completed surveys. This identifying information was not recorded on the surveys themselves.

In total, 585 usable surveys were returned. Participants were asked to answer the substantive federal individual income tax statements which are shown in Table 2. The participants were asked to respond to these 14 questions by filling in the appropriate circle where $1=$ Strongly agree, $2=$ Somewhat agree, $3=$ Neither agree nor disagree/neutral, $4=$ Somewhat disagree, and $5=$ Strongly disagree.

In addition to the 14 substantive questions, several demographic questions were also included in the survey. One of those demographic questions asked respondents to indicate their political party affiliation, and 565 individuals answered this question. Thirty-seven percent of the respondents (209) identified themselves as being affiliated with the Republican Party, 27\% with the Democrat Party (155), 15\% as Independents (85), and 21\% responded that they did not belong to a political party (116). Another demographic question asked respondents to indicate their ideological philosophy (conservative, moderate, or liberal). Forty-nine percent of the respondents described themselves as moderates, $36 \%$ as conservatives, and $15 \%$ as liberals.

\section{Political Party Affiliation}

Table 1 summarizes the observed relationship between political party affiliation and ideological philosophy. Only 560 of the survey respondents answered both the political party affiliation question and the ideological philosophy question. Therefore, the crosstabulation report in Table 1 shows the results for those 560 respondents. Note, for example, that $8.4 \%$ of the respondents who identified themselves as Democrats indicated that their ideological philosophy was conservative, while $67.8 \%$ of Republicans indicated that their ideological philosophy was conservative. In contrast, $38.3 \%$ of the Democrats responded that their ideological philosophy was liberal, but only $0.5 \%$ of the Republicans responded that their ideological philosophy was liberal. Approximately $53 \%$ of the Democrats, $67 \%$ of the Independents, $32 \%$ of the Republicans, and $63 \%$ with no political party affiliation responded that their ideological philosophy was moderate. 
Table 1: Observed Relationship between Political Party Affiliation and Ideological Philosophy

\begin{tabular}{|l|c|c|c|c|}
\hline & Democrat & Independent & Republican & No Party Affiliation \\
\hline Conservative & $13(8.4 \%)$ & $18(21.4 \%)$ & $141(67.8 \%)$ & $30(26.3 \%)$ \\
\hline Moderate & $82(53.3 \%)$ & $56(66.7 \%)$ & $66(31.7 \%)$ & $72(63.2 \%)$ \\
\hline Liberal & $59(38.3 \%)$ & $10(11.9 \%)$ & $1(0.5 \%)$ & $12(10.5 \%)$ \\
\hline Total & $154(100 \%)$ & $84(100 \%)$ & $208(100 \%)$ & $114(100 \%)$ \\
\hline
\end{tabular}

For both the political party and ideological philosophy demographic questions, the responses to the 14 substantive questions were tabulated and statistically analyzed using the Pearson chi-square test of independence. With regard to political party affiliation, the null hypothesis for the chi-square test is that the response provided to a statement is independent of political party, while the alternative hypothesis is that the response provided to the statement is not independent of (i.e., does depend upon) political party. As indicated in Table 2, with the exception of statements 1 and 3, statistically significant differences were identified for all of the remaining statements. That is, the null hypothesis is rejected for 12 of the 14 statements.

Table 2: Statistically Significant Difference in Responses Based on Political Party and Ideological Philosophy

\begin{tabular}{|c|c|c|}
\hline Statement & $\begin{array}{l}\text { Political Party } \\
\text { Affiliation }\end{array}$ & $\begin{array}{l}\text { Ideological } \\
\text { Philosophy }\end{array}$ \\
\hline $\begin{array}{l}\text { 1. Federal individual income tax policy should be based primarily on the current economic } \\
\text { climate. }\end{array}$ & & $*$ \\
\hline $\begin{array}{l}\text { 2. The federal budget deficit should be reduced through increases in the federal individual } \\
\text { income tax. }\end{array}$ & $* *$ & $* *$ \\
\hline 3. All taxpayers should pay at least some minimum amount of federal individual income tax. & & *** \\
\hline 4. An individual's federal income tax obligation should be based on his or her ability to pay. & $* *$ & $* *$ \\
\hline 5. As taxable income increases, individual income tax rates should also increase. & $* *$ & $* *$ \\
\hline $\begin{array}{l}\text { 6. High income taxpayers should be subject to higher individual income tax rates than those } \\
\text { taxpayers with less income. }\end{array}$ & $* *$ & $* *$ \\
\hline $\begin{array}{l}\text { 7. When the economy is strong, all taxpayers should be subject to higher individual income } \\
\text { tax rates. }\end{array}$ & $* *$ & $* *$ \\
\hline $\begin{array}{l}\text { 8. Federal individual income tax rules and rates should remain consistent from year to year } \\
\text { for everyone regardless of income level or economic conditions. }\end{array}$ & $*$ & $* *$ \\
\hline $\begin{array}{l}\text { 9. When the economy is weak, high income taxpayers should be subject to higher individual } \\
\text { income tax rates than when the economy is strong. }\end{array}$ & $* *$ & $* *$ \\
\hline 10. Low income taxpayers should not be subject to the federal individual income tax. & $*$ & $* *$ \\
\hline $\begin{array}{l}\text { 11. High income taxpayers should be obligated to pay more than their proportionate share of } \\
\text { federal individual income taxes. }\end{array}$ & $* *$ & $* *$ \\
\hline 12. The federal budget deficit should be reduced through spending cuts. & *** & $* *$ \\
\hline $\begin{array}{l}\text { 13. Federal individual income tax rates should generally be relatively lower during poor } \\
\text { economic times. }\end{array}$ & $* *$ & \\
\hline $\begin{array}{l}\text { 14. Federal individual income tax policy should be used to address the US government debt } \\
\text { ceiling controversy. }\end{array}$ & $*$ & $*$ \\
\hline
\end{tabular}

* Significant at the 0.05 level; ** Significant at the 0.01 level

Table 3 highlights the differences for the "strongly agree" and "strongly disagree" categories based on political party affiliation. To assist in the interpretation of Table 3, consider the following discussion for the two statements that asked about different approaches for reducing the federal budget deficit.

For statement 2, "The federal budget deficit should be reduced through increases in the federal individual income tax," only a small percentage (7.7\%) of all respondents selected the "strongly agree" category. Nevertheless, survey participants who identified themselves as being affiliated with the Democrat Party and individuals not belonging to a political party strongly agreed to the statement more than what would be expected under the assumption of independence, while Republicans strongly agreed less than what would be expected. Independents selected the "strongly agree" category quite closely to what would be expected under the assumption of independence. ( $10.5 \%$ of the Democrats, $7.1 \%$ of the Independents, $3.4 \%$ of the Republicans, and $12.1 \%$ with no political party affiliation responded "strongly agree.") A larger percentage of respondents overall (23.4\%) selected 
the "strongly disagree" category for statement 2. However, fewer Democrats and Independents than expected selected this option, while more Republicans than expected selected "strongly disagree." Individuals not belonging to a political party selected "strongly disagree" very closely to what would be expected under the assumption of independence between the response provided and political party affiliation. (12.5\% of the Democrats, $16.5 \%$ of the Independents, $34.6 \%$ of the Republicans, and $22.4 \%$ with no political party affiliation responded "strongly disagree.") The p-value associated with the chi-square test for statement 2 was 0.000 .

For statement 12, "The federal budget deficit should be reduced through spending cuts," a much larger percentage of all respondents $(41.3 \%)$ selected the "strongly agree" category. Survey participants who identified themselves as being affiliated with the Democrat Party strongly agreed to the statement less than what one would expect under the assumption of independence, while Republicans strongly agreed more than what would be expected. Independents and individuals with no political party affiliation strongly agreed very closely to what would be expected under the assumption of independence. (24.7\% of the Democrats, $40.0 \%$ of the Independents, $55.0 \%$ of the Republicans, and $39.7 \%$ with no political party affiliation responded "strongly agree.") Overall, only $4.3 \%$ of the survey participants selected the "strongly disagree" category for statement 12 . In fact, all four groups (Democrats, Independents, Republicans, and individuals with no political party affiliation) selected "strongly disagree" quite closely to what would be expected under the assumption of independence between the response provided and political party affiliation. (5.8\% of the Democrats, 3.5\% of the Independents, 3.3\% of the Republicans, and $4.3 \%$ with no political party affiliation responded "strongly disagree.") The p-value associated with the chi-square test for statement 12 was 0.000 .

Table 3: Political Party Affiliation

\begin{tabular}{|c|c|c|c|c|c|c|c|c|}
\hline & \multicolumn{4}{|c|}{ Strongly Agree } & \multicolumn{4}{|c|}{ Strongly Disagree } \\
\hline Statement & Dem & Ind & Repub & No Party & Dem & Ind & Repub & No Party \\
\hline 2 & MTE & $\begin{array}{c}\text { As } \\
\text { expected }\end{array}$ & LTE & MTE & LTE & LTE & MTE & $\begin{array}{c}\text { As } \\
\text { expected }\end{array}$ \\
\hline 4 & MTE & $\begin{array}{c}\text { As } \\
\text { expected }\end{array}$ & LTE & $\begin{array}{c}\text { As } \\
\text { expected }\end{array}$ & LTE & $\begin{array}{c}\text { As } \\
\text { expected }\end{array}$ & MTE & LTE \\
\hline 5 & MTE & $\begin{array}{c}\text { As } \\
\text { expected }\end{array}$ & LTE & $\begin{array}{c}\text { As } \\
\text { expected }\end{array}$ & LTE & $\begin{array}{c}\text { As } \\
\text { expected }\end{array}$ & MTE & $\begin{array}{c}\text { As } \\
\text { expected }\end{array}$ \\
\hline 6 & MTE & $\begin{array}{c}\text { As } \\
\text { expected }\end{array}$ & LTE & LTE & LTE & $\begin{array}{c}\text { As } \\
\text { expected }\end{array}$ & MTE & $\begin{array}{c}\text { As } \\
\text { expected }\end{array}$ \\
\hline 7 & $\begin{array}{c}\text { As } \\
\text { expected }\end{array}$ & $\begin{array}{c}\text { As } \\
\text { expected }\end{array}$ & LTE & MTE & LTE & $\begin{array}{c}\text { As } \\
\text { expected }\end{array}$ & MTE & $\begin{array}{c}\text { As } \\
\text { expected }\end{array}$ \\
\hline 8 & LTE & $\begin{array}{c}\text { As } \\
\text { expected }\end{array}$ & MTE & LTE & $\begin{array}{c}\text { As } \\
\text { expected }\end{array}$ & $\begin{array}{c}\text { As } \\
\text { expected }\end{array}$ & $\begin{array}{c}\text { As } \\
\text { expected }\end{array}$ & MTE \\
\hline 9 & MTE & LTE & LTE & $\begin{array}{c}\text { As } \\
\text { expected }\end{array}$ & LTE & LTE & MTE & $\begin{array}{c}\text { As } \\
\text { expected }\end{array}$ \\
\hline 10 & $\begin{array}{c}\text { As } \\
\text { expected }\end{array}$ & LTE & LTE & MTE & LTE & $\begin{array}{c}\text { As } \\
\text { expected }\end{array}$ & MTE & $\begin{array}{c}\text { As } \\
\text { expected }\end{array}$ \\
\hline 11 & MTE & LTE & LTE & $\begin{array}{c}\text { As } \\
\text { expected }\end{array}$ & LTE & $\begin{array}{c}\text { As } \\
\text { expected }\end{array}$ & MTE & $\begin{array}{c}\text { As } \\
\text { expected }\end{array}$ \\
\hline 12 & LTE & $\begin{array}{c}\text { As } \\
\text { expected }\end{array}$ & MTE & $\begin{array}{c}\text { As } \\
\text { expected }\end{array}$ & $\begin{array}{c}\text { As } \\
\text { expected }\end{array}$ & $\begin{array}{c}\text { As } \\
\text { expected }\end{array}$ & $\begin{array}{c}\text { As } \\
\text { expected }\end{array}$ & $\begin{array}{c}\text { As } \\
\text { expected }\end{array}$ \\
\hline 13 & LTE & LTE & $\begin{array}{c}\text { As } \\
\text { expected }\end{array}$ & MTE & $\begin{array}{c}\text { As } \\
\text { expected }\end{array}$ & $\begin{array}{c}\text { As } \\
\text { expected }\end{array}$ & $\begin{array}{c}\text { As } \\
\text { expected }\end{array}$ & $\begin{array}{c}\text { As } \\
\text { expected }\end{array}$ \\
\hline 14 & MTE & $\begin{array}{c}\text { As } \\
\text { expected }\end{array}$ & LTE & $\begin{array}{c}\text { As } \\
\text { expected }\end{array}$ & LTE & LTE & MTE & $\begin{array}{c}\text { As } \\
\text { expected }\end{array}$ \\
\hline
\end{tabular}

MTE $=$ More responses than expected under the assumption of independence; LTE $=$ Less responses expected than under the assumption of independence

\section{Ideological Philosophy}

In the case of ideological philosophy, the null hypothesis for the chi-square test is that the response provided to a statement is independent of ideological philosophy, while the alternative hypothesis is that the response provided to the statement is not independent of (or does depends upon) ideological philosophy. As 
indicated in Table 2, with the exception of statement 13, statistically significant differences were identified for all of the other statements. That is, the null hypothesis is rejected for 13 of the 14 statements. Table 4 highlights the differences for the "strongly agree" and "strongly disagree" categories based on ideological philosophy. To mirror the discussion above for political party affiliation, consider once again the two statements that asked about different approaches for reducing the federal budget deficit.

As was noted earlier in the political party affiliation discussion, only $7.7 \%$ of all respondents selected the "strongly agree" category for statement 2 , "The federal budget deficit should be reduced through increases in the federal individual income tax." Survey participants who identified themselves as liberals strongly agreed to the statement more than what would be expected under the assumption of independence, while conservatives strongly agreed less than what would be expected. Moderates selected "strongly agree" fairly closely to what would be expected under the assumption of independence between the response provided and ideological philosophy. (2.9\% of the conservatives, $7.6 \%$ of the moderates, and $21.0 \%$ of the liberals responded "strongly agree.") For statement 2 , $23.4 \%$ of all respondents selected the "strongly disagree" category. More conservatives than expected selected this option, while fewer moderates and liberals than expected selected "strongly disagree." (37.2\% of the conservatives, $17.6 \%$ of the moderates, and $12.3 \%$ of the liberals responded "strongly disagree.") The p-value associated with the chi-square test for statement 2 was 000 .

Table 4: Ideological Philosophy

\begin{tabular}{|c|c|c|c|c|c|c|}
\hline & \multicolumn{3}{|c|}{ Strongly Agree } & \multicolumn{3}{c|}{ Strongly Disagree } \\
\hline Statement & Conservative & Moderate & Liberal & Conservative & Moderate & Liberal \\
\hline $\mathbf{1}$ & As expected & As expected & As expected & MTE & As expected & LTE \\
\hline $\mathbf{2}$ & LTE & As expected & MTE & MTE & LTE & LTE \\
\hline $\mathbf{3}$ & MTE & LTE & As expected & As expected & As expected & MTE \\
\hline $\mathbf{4}$ & LTE & As expected & MTE & MTE & As expected & LTE \\
\hline $\mathbf{5}$ & As expected & LTE & MTE & MTE & LTE & LTE \\
\hline $\mathbf{6}$ & LTE & LTE & MTE & MTE & As expected & LTE \\
\hline $\mathbf{7}$ & As expected & As expected & As expected & MTE & LTE & As expected \\
\hline $\mathbf{8}$ & MTE & As expected & LTE & MTE & LTE & As expected \\
\hline $\mathbf{9}$ & As expected & As expected & MTE & MTE & LTE & LTE \\
\hline $\mathbf{1 0}$ & LTE & As expected & As expected & MTE & As expected & LTE \\
\hline $\mathbf{1 1}$ & As expected & LTE & MTE & MTE & LTE & LTE \\
\hline $\mathbf{1 2}$ & MTE & LTE & LTE & LTE & As expected & MTE \\
\hline $\mathbf{1 4}$ & As expected & As expected & As expected & MTE & LTE & LTE \\
\hline
\end{tabular}

MTE $=$ More responses than expected under the assumption of independence; LTE $=$ Less responses expected than under the assumption of independence

For statement 12, "The federal budget deficit should be reduced through spending cuts," $41.3 \%$ selected the "strongly agree" category." Survey participants who identified themselves as conservatives strongly agreed to the statement more than what would be expected under the assumption of independence, while moderates and liberals strongly agreed less than what would be expected. (59.4\% of the conservatives, $34.1 \%$ of the moderates, and $25.3 \%$ of the liberals responded "strongly agree.") Roughly four percent (4.3\%) of all survey participants selected the "strongly disagree" category for statement 12 . Fewer conservatives than expected selected this option, while more liberals than expected selected "strongly disagree." Moderates selected "strongly disagree" very closely to what would be expected under the assumption of independence between the response provided and ideological philosophy. (2.4\% of the conservatives, $4.7 \%$ of the moderates, and $7.2 \%$ of the liberals responded "strongly disagree.”) The p-value associated with the chi-square test for statement 12 was 0.000 .

\section{Summary of Similarities}

The summary of results in Tables 3 and 4 illustrates numerous similarities in a person's response to a statement based on his/her political party affiliation and ideological philosophy. In fact, when considering respondents who answered either Republican or Democrat to the political party affiliation demographic question and those who answered either conservative or liberal to the ideological philosophy question, there is a strong positive correlation equal to +0.855 . 
For the statements that were found to be statistically significant based on the demographic questions about political party affiliation and ideological philosophy, Table 5 provides a summary of the similarities for Republicans versus conservatives and for Democrats versus liberals. Consider the Table 5 entries associated with statement 2 , "The federal budget deficit should be reduced through increases in the federal individual income tax." The table illustrates that Republicans and conservatives selected "strongly agree" less than expected under the assumption of independence, while Democrats and liberals selected "strongly agree" more than expected. However, Republicans and conservatives selected "strongly disagree" for statement 2 more than expected, while Democrats and liberals strongly disagreed less than expected.

Table 5: Similarities between Political Party Affiliation and Ideological Philosophy

\begin{tabular}{|c|c|c|c|c|c|c|c|c|}
\hline & \multicolumn{4}{|c|}{ Strongly Agree } & \multicolumn{4}{|c|}{ Strongly Disagree } \\
\hline Statement & Rep & Conserv & Dem & Liberal & Rep & Conserv & Dem & Liberal \\
\hline 2 & LTE & LTE & MTE & MTE & MTE & MTE & LTE & LTE \\
\hline 4 & LTE & LTE & MTE & MTE & MTE & MTE & LTE & LTE \\
\hline 5 & LTE & $\begin{array}{c}\text { As } \\
\text { expected }\end{array}$ & MTE & MTE & MTE & MTE & LTE & LTE \\
\hline 6 & LTE & LTE & MTE & MTE & MTE & MTE & LTE & LTE \\
\hline 7 & LTE & $\begin{array}{c}\text { As } \\
\text { expected }\end{array}$ & $\begin{array}{c}\text { As } \\
\text { expected }\end{array}$ & $\begin{array}{c}\text { As } \\
\text { expected }\end{array}$ & MTE & MTE & LTE & $\begin{array}{c}\text { As } \\
\text { expected }\end{array}$ \\
\hline 8 & MTE & MTE & LTE & LTE & $\begin{array}{c}\text { As } \\
\text { expected }\end{array}$ & MTE & $\begin{array}{c}\text { As } \\
\text { expected }\end{array}$ & $\begin{array}{c}\text { As } \\
\text { expected }\end{array}$ \\
\hline 9 & LTE & $\begin{array}{c}\text { As } \\
\text { expected }\end{array}$ & MTE & MTE & MTE & MTE & LTE & LTE \\
\hline 10 & LTE & LTE & $\begin{array}{c}\text { As } \\
\text { expected }\end{array}$ & $\begin{array}{c}\text { As } \\
\text { expected }\end{array}$ & MTE & MTE & LTE & LTE \\
\hline 11 & LTE & $\begin{array}{c}\text { As } \\
\text { expected }\end{array}$ & MTE & MTE & MTE & MTE & LTE & LTE \\
\hline 12 & MTE & MTE & LTE & LTE & $\begin{array}{c}\text { As } \\
\text { expected }\end{array}$ & LTE & $\begin{array}{c}\text { As } \\
\text { expected }\end{array}$ & MTE \\
\hline 14 & LTE & $\begin{array}{c}\text { As } \\
\text { expected }\end{array}$ & MTE & $\begin{array}{c}\text { As } \\
\text { expected }\end{array}$ & MTE & MTE & LTE & LTE \\
\hline
\end{tabular}

LTE $=$ Less responses expected than under the assumption of independence; MTE $=$ More responses than expected under the assumption of independence

\section{FURTHER ANALYSIS}

In addition to the tests of independence, statistical tests were conducted to determine whether or not the proportion of responses associated with the ideological philosophy demographic category (Conservative, Moderate, and Liberal) differed from one another. The visual display in Table 6 summarizes the "strongly agree" (SA) and "strongly disagree" (SD) responses for the statistically significant statements for this demographic using a 0.05 level of significance. Consider the following explanations to assist in the interpretation of these visual displays. When a line joins two ideological philosophy categories, the proportions are not significantly different. Thus, for the "strongly agree" category in statement one, the proportions of those with Conservative, Moderate and Liberal ideological philosophies who responded "strongly agree" are not significantly different. However, for the "strongly disagree" category in statement one, the proportion of Conservatives who responded "strongly disagree" is significantly different from the other two groups. There is no statistical evidence of a significant difference in the proportion of responses between Moderate and Liberal for the "strongly disagree" row in statement one. For statement two, there is a significant difference in the proportion of "strongly agrees" among all three groupings because there is a break in the lines between "Conservative," "Moderate" and "Liberal" in the "strongly agree" row. For the "strongly disagree" category in statement 2, the proportion of Conservatives who responded "strongly disagree" is significantly different from the other two groups. There is no statistical evidence of a significant difference in the proportion of responses between Moderate and Liberal for the "strongly disagree" row in statement two. 
Table 6: Ideological Philosophy

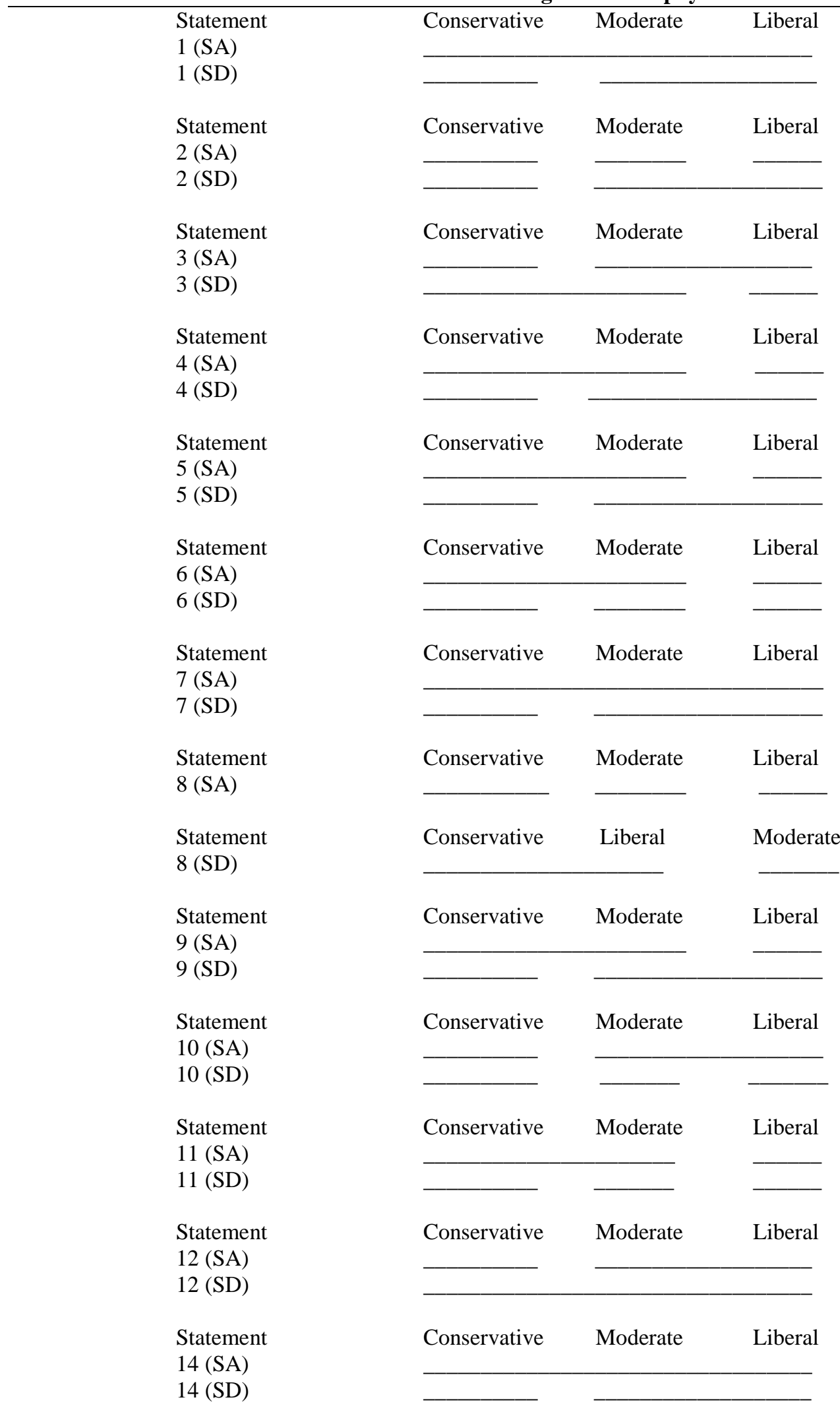




\section{CONCLUSIONS}

Individuals who are affiliated with different political parties and who subscribe to different ideological philosophies also tend to have different views on a number of issues. Consistent with expectations, a conservative ideology was found to be more prevalent among Republicans in the sample used in this study, and a liberal perspective was more prevalent among Democrats. It is interesting to note that the majority of Democrats, Independents and those respondents with no political party affiliation indicated that they subscribed to a moderate ideological philosophy. The Republicans were the outliers, with only $32 \%$ of them indicating that they were moderates.

Responses to the 14 federal individual income tax statements that were included in this survey were statistically analyzed; the analysis revealed that in the case of almost all of the statements, the responses were not independent of political party or ideological philosophy. In other words, the response depended upon the respondent's political party or ideological philosophy. These results illustrate numerous similarities in a person's response to a statement based on his/her political party affiliation and ideological philosophy. There was a +0.855 correlation between respondents who answered either Republican or Democrat to the political party affiliation demographic question and those who answered either conservative or liberal to the ideological philosophy question.

With increasing frequency, the news media is reporting that the United States will soon face a "fiscal cliff." This is likely to continue as the 2012 presidential election is past. As with many fiscal and tax-related issues, this study provides evidence that individuals with different political party affiliations and different ideological philosophies have different views regarding the federal individual income tax. These results suggest that the outcome of the presidential and Congressional elections may, indeed, have an impact on the future decisions with respect to the federal individual income tax as there appear to be differences of opinion along both political party and ideological philosophy lines. The question remains whether these differences can be set aside in a consolidated effort to find long range solutions to our country's fiscal challenges. If neither party wins control of the president's office and the House and Senate, there does not appear to be much hope for a quick and decisive plan to address this critical situation.

\section{AUTHOR INFORMATION}

Dr. Angeline M. Lavin earned her Ph.D. at the University of Nebraska, Lincoln in 1997. Currently she is a professor of finance at the University of South Dakota where she also serves at the Graduate Business Programs Directors. Contact at: Angeline Lavin, Ph.D., Beacom School of Business, University of South Dakota, 414 E. Clark Street, Vermillion, SD 57069 USA. E-mail: Angeline.Lavin@usd.edu (Corresponding author)

Dr. David H. Moen earned his Ph.D. at Oklahoma State University in 1983. Currently he is a professor of statistics at the University of South Dakota. Contact at: David Moen, Ph.D., Beacom School of Business, University of South Dakota, 414 E. Clark Street, Vermillion, SD 57069 USA. E-mail: dmoen@usd.edu

Dr. Thomas L. Davies earned his LL.M. in Tax at the University of Missouri, Kansas City in 1992. Currently he is a professor of accounting at the University of South Dakota where he also serves as the Associate Dean of the Beacom School of Business. Contact at: Thomas Davies, L.L.M., Beacom School of Business, University of South Dakota, 414 E. Clark Street, Vermillion, SD 57069 USA. E-mail: thavies@usd.edu

\section{REFERENCES}

1. Ackerman, J. and R. Altshuler (2006). Constrained Tax Reform: How political and Economic Constraints Affect the Formation of Tax Policy Proposals. National Tax Journal, 59(1), 165-187.

2. Acuna, Hernan and Randall G. Holcombe. (2010). The Effect of Changes in the Tax Structure on the Reported Income of High-Income Individuals. Public Finance Review, 38 (30), 321-345.

3. Auten, Geral, Robert Carroll, and Geoffery Gee. (2008) The 2001 and 2003 Tax Rate Reductions: An Overview and Estimate of the Taxable Income Response. National Tax Journal, 61 (30), 345-364. 
4. Auten, Gerald and Geoffrey Gee. (2009). Income Mobility in the United States: New Evidence from Income Tax Data. National Tax Journal, 62 (2), 301-328.

5. Bartels, Larry M. (2000). Partisanship and Voting Behavior, 1952-1996. American Journal of Political Science, 44 (January): 35-50.

6. Burman, L., W. Gale, G. Leiserson, and J. Rohaly. (2007). The AMT: What's Wrong and How to Fix It. National Tax Journal, 60 (3), 385-405.

7. Citizens for Tax Justice. (November 2011). Top Federal Income Tax Rates since 1913. Retrieved from: http://www.ctj.org/pdf/regcg.pdf

8. Feldstein, Martin. (March 2008). Effects of Taxes on Economic Behavior. National Tax Journal, 61 (1), 131-139.

9. Ferguson, Niall. (August 27, 2012). Why Obama Must Go. Newsweek, 21-25.

10. Frum, David. (August 13 and 20, 2012). America the Anxious. Newsweek, 38-42.

11. Greeley, Brendan. (August 30, 2012). They Can’t Be Serious. Bloomberg Business Week, 4-5.

12. Hetherington, Marc J. (2001). Resurgent Mass Partisanship: The Role of Elite Polarization. American Political Science Review, 95 (30), 619-631.

13. Hofman, Eva, Erik Hoelzl, and Erich Kirchler. (2008). Preconditions of Voluntary Tax Compliance: Knowledge and Evaluation of Taxation, Norms, Fairness, and Motivation to Cooperate. Journal of Psychology, 216 (4), 209-217.

14. Jacoby, William. (1988). The Impact of Party Identification on Issue Attitudes. American Journal of Political Science, 32 (3), 643-661.

15. Krupnikov, Y., A. Levine, A. Lupia, and M. Prior. (2006). Public Ignorance and Estate Tax Repeal: The Effect of Partisan Differences and Survey Incentives. National Tax Journal, 59 (3), 425-437.

16. Litan, R. (1999). Expanding the Winners Circle: A Guide for Increasing Upward Mobility, Blueprint Magazine Washington, DC: Brookings Institute. Retrieved from: http://www.brookings.edu/articles/199/winter_useeconomics_litan.aspx.

17. Meckler, Laura and Damian Paletta. (July 10, 2012). Obama Intensifies Tax Fight. Wall Street Journal, CCLX (1), A1 and A4.

18. Miller, Warren E. (1998). Party Identification and the Electorate of the 1990s. In The Parties Respond: Changes in American Parties and Campaigns, 3d ed., ed. L. Sandy Masiel. Boulder, CO: Westview, 10927.

19. Peter, Klara Sabirianova, Steve Buttrick, and Denvil Duncan. (2010). Global Reform of Personal Income Taxation, 1981-2005: Evidence from 189 Countries. National Tax Journal, 63 (3), 447-478.

20. Porter, Eduardo. (March 28, 2012). The Case for Raising Top Tax Rates. The New York Times, B1.

21. Seib, Gerald. (July 10, 2012). "No Sign of Voter Polarization Warning." Wall Street Journal, CCLX, 7, A4. 
NOTES 